\section{Dr. F. C. Steward}

Dr. F. C. Steward, reader in plant physiology in Birkbeck College, University of London, has recently left for the United States to take up a temporary appointment as research associate in the University of Chicago, where he is to develop certain aspects of plant physiology and biochemistry in which Prof. E. J. Kraus and the Chicago Department of Botany are interested. Dr. Steward has been given leave of absence by Birkbeck College for this purpose, and the appointment is a sequel to the destruction in an air raid of the research laboratory in plant physiology at Birkbeck, which had been largely equipped by the Rockefeller Foundation. Dr. Steward has been engaged since 1941 with the Ministry of Aircraft Production, where he developed a department dealing with statistics concerning the determination and forecasting of Royal Air Force requirements. It seemed that his return to botanical research would be delayed indefinitely by the destruction of his laboratory, so that the offer of Prof. Kraus has rendered a real service to botanical inquiry.

Mrs. Neville-Rolfe, O.B.E.

Mrs. Neville-Rolfe has resigned her office as honorary secretary of the British Social Hygiene Council. Fortunately this does not mean a severance of her interest in the Council. She has been elected a vice-president, and has also accepted a new office of honorary adviser, which will enable her to place at its disposal her great store of accumulated knowledge and experience. As honorary secretary of the National Council for Combating Venereal Disease from its foundation thirty years ago, she took the principal part in organizing the whole scheme of popular education in this subject-one hitherto taboo. In these early days the work of popular enlightenment on venereal disease was financed by a direct grant from the Exchequer; but the difficulty lay in persuading local authorities to avail themselves of the educational material offered by the Council, and in overcoming the resistance of many hospital authorities to the establishment of free clinics. In this work, and also in the organization of lectures to the armed forces during the War of 1914-18, Mrs. Neville-Rolfe was indefatigable.

As the years passed, it became increasingly obvious that the problem of venereal disease was only one aspect of a larger one, that of social hygiene in its wide sense, and that the Council's work should cover this wider field so as to combat the causes leading to sexual misconduct-the absence of biological teaching of the adolescent, the lack of training of teachers and instruction of parents, and the need for amelioration of various relevant social malconditions. At the same time, the name was changed to British Social Hygiene Council, and Mrs. Neville-Rolfe organized the wider field with undiminished zeal. In addition, however, to this work on the home front, she was able to extend its scope to the Dominions and the Colonies, in many of which branches and colleague organizations were established. Through the collaboration of the Government Departments concerned, several overseas visits and commissions were arranged and carried out by the Council between the years 1920 and 1936. Mrs. Neville-Rolfe, in 1926, spent six months in India, touring many provinces and States on the invitation of their respective Governments. She also, at various times, visited Canada, the Far East, Palestine, Cyprus, Jamaica and Southern Rhodesia, investigating local conditions and organizing measures for reducing the incidence of venereal disease. Liaison was also established internationally with the various foreign societies working in this field, and she was one of the founders of the Union Internationale Contre le Péril Vénérien, holding office as vice-president, and chairman of its Ports Commission. In 1941, she was awarded the Snow Gold Medal of the American Social Hygiene Council for work in social hygiene (Nature, $147,261 ; 1941)$.

\section{Chemical Technology at Imperial College}

The Imperial College of Science and Technology, with the approval of the Court of the University of London, has lately accepted from Messrs. Courtaulds; Ltd., a benefaction intended to promote its work in the field of chemical technology. This benefaction, which is calculated to yield an income of $£ 3,000$ per annum in perpetuity, will be administered for the present by a small body of trustees, and will permit the institution in Imperial College of a Courtaulds chair of chemical engineering, to which it is expected that an appointment will be made this year. It will also provide for other needs in the Department of Chemical Technology, in ways that will be decided by the trustees after consultation with the College. The Governing Body of Imperial College has recorded their most grateful appreciation of the gift, which is an outstanding event of this centenary year.

\section{Visits of French and Relgian Medical and Scientific Workers}

A French medical delegation of ten is visiting Great Britain during April 7-17 as guests of the British Council, in conjunction with the Royal College of Physicians, and will be entertained by other organizations, including the Royal Society of Medicine. The delegation will see hospitals in London and elsewhere and visit Oxford and Cambridge. The members are: Académie de Médecine: Prof. Baudouin, dean of the Faculty of Medicine, Paris, Prof. A. Lemierre and Dr. P. F. Armand-Delille; Conseil Supérieur de Médecine: Dr. Ravina, Dr. A. Laporte and Dr. H. Descomps; Provinces: Prof. C. Soula (Toulouse), Prof. Gernez-Rieux (Lille), Prof. Roche (Marseilles) and Dr. Nedelec (Angers). The first of four groups of representatives from Belgian universities, whose visits are being arranged by the Belgian Fondation Universitaire, will be in Britain during April 16-30. The other groups will follow at intervals between May and July. The members of the first group are: Prof. V. Bohet, professor of English, Liège; Prof. N. Goormachtigh, Faculty of Medicine, Ghent; Prof. P. Govaerts, Faculty of Medicine, Brussels ; Prof. M. F. L. Hemptinne, Faculty of Seience, Louvain; Prof. C. J. Jungers, Faculty of Science, Louvain.

\section{Bibliography of the British Flora}

WrTH the view of eventual publication, it is proposed to compile a bibliography of the British Flora. One section of this, on local botany, would comprise all publications, which it is possible to trace, dealing wholly or partly with the flora of any area within the British Isles. This section would include local floras and works on topographical botany, and all publications, such as local and county histories, guide books, periodicals and newspapers, etc., in which plant lists of particular areas have appẹared; manu- 